\title{
PROJECT BASED LEARNING THROUGH SEVIMA EDLINK APPS TO IMPROVE STUDENTS' ACADEMIC WRITING OF EDUCATION PROGRAM AT STKIP KUSUMANEGARA
}

\author{
Dini Fitriani; Awin Alaby; Wisnu Kala Kusumajati \\ STKIP KUSUMANEGARA \\ Jakarta, Indonesia \\ dinifitriani@stkipkusumanegara.ac.id alaby@stkipkusumanegara.ac.id wisnukala@stkipkusumanegara.ac.id
}

\begin{abstract}
Distance Learning is a big challenge for the world of education because not all have experienced it before. Project Based Learning (PBL) through Edlink Sevima Application is one alternative that can be applied by lecturers in Distance Learning activities. The purpose of this study was to determine whether the Project Based Learning (PBL) as Learning Model through the Edlink Sevima Application could improve the academic writing skills of students of the English Education Study Program at STKIP Kusumanegara. This research was conducted with a Classroom Action Research (CAR) research approach which consisted of two learning cycles with 18 students. The data collection technique used is through observation, interviews, and student academic writing tests. The results of this study can be seen by using the Project Based Learning model through edlink sevima which can improve students' academic writing test results from two learning cycles given a minimum completeness score of 75 and a success target of $85 \%$. In the first cycle students were able to achieve the target of $6 i \%$ and the second cycle $90 \%$. Based on the results of the study, it can be said that the Project Based Learning as a learning model through the Sevima edlink application is effective in improving students' academic writing skills in distance learning.
\end{abstract}

Keyword: Project Based Learning, Edlink Sevima, Academic Writing.

\section{INTRODUCTION}

Mastery of English academic writing skills for students of the English Education Study Program, STKIP Kusumanegara is one of the skills that must be mastered as a condition for submitting a thesis title. Besides that, academic writing in English is also a must for international class students where English is a tool of oral and written communication in the learning process. In addition, these skills are needed when entering the workforce, communicating in writing with foreigners, facing written exams such as TOEFL and IELTS or if students are going to continue their master's degree abroad. There are so many offers for students from outside countries that can be registered by Indonesian students who want to continue their studies to a higher level. Likewise, English academic writing skills are very useful for students in writing their college assignments. Therefore, from the start, students must be equipped with academic skills in writing English. However, in reality, the mastery of English academic 
writing skills for the students of the English Education Study Program, especially the 6th semester of STKIP Kusumanegara, is still very lacking. This is evidenced by the low scores of students' English academic writing results, as well as the difficulty of writing articles in English, papers for discussions/seminars or symposiums, including papers to fulfill assignments for a course. Likewise, there were complaints from several lecturers. This is also proven when the English lecturer orders academic writing in English, the students make many grammatical errors and are still far from the criteria for good and correct academic writing.

Based on the gaps that occur, of course, lecturers have made various efforts, including: lecturers provide various ways to grow students' motivation to write, learning by doing. Students are given the task and obligation to write in various ways, for example writing articles, scientific works, or just activity reports. One way that is often done is to ask students to read a book and then they have to make a summary of the contents of the book they have read. Although English lecturers often attend seminars, workshops or trainings both at home and abroad on learning to write English academically, the efforts made by English lecturers have not been able to overcome the problems faced by students.
In addition to the above problems, with the COVID-19 pandemic, learning activities are required by distance learning, but this does not reduce the goal of researchers in improving the academic writing skills of English students in Semester 6 of the STKIP Kusumanegara English Education Study Program in 20202021 by using the Project Based Learning (PBL) learning model through Edlink Sevima which is expected to provide one solution to the problem of English academic writing skills and provide provisions in facing challenges at higher institutions or in the world of work in this global era.

Thus, it is necessary to conduct action research to improve English academic writing skills through the dictogloss teaching technique for 6th semester students of the STKIP Kusumanegara English Education Study Program. When viewed from one of the objectives of the dictogloss teaching technique, that dictogloss is designed to increase the use of language both written and spoken. In written English for example at schools, diplomas, or universities where students are expected to be able to write cohesive texts (such as in writing essays, coursework, research reports, theses, theses etc.), while academic writing itself when viewed from the definition is the skill of 
writing or scientific writing that is prepared to obtain an academic degree. In addition, scientific papers are prepared in the writing of papers and research reports in the institutional environment by complying with the rules of correct English academic writing.

\section{Project based Learning (PBL) learning method)}

With the pandemic conditions requiring distance learning, researchers took the initiative to provide Project based learning (PBL) learning methods in improving students' academic writing skills. The Project Based Learning (PBL) learning method is used along with a Concept Map. In the article of Thomas said project-based learning is a learning model that provides an opportunity for lecturers to manage learning in the classroom by involving project work (Thomas, 2000). Project-based learning is a learning method that can help students build their thinking and communication skills. Project Based Learning generally has the following steps: Planning (planning), Creating (implementation) and Processing.

Project Based Learning can help students in group study, develop skills and the projects they work on are able to provide personal experiences to students and can emphasize student-centered learning activities. Thus, the lecturer no longer acts as a learning resource but only as a facilitator, meaning that the lecturer helps more students to learn, the lecturer also monitors student activities in the learning process. In Bagheri's research in his journal project-based learning can improve student achievement and learning activities. In Anggriani's research, it was stated that students who were given learning using the project method had higher achievements than students who were given learning using the experimental method.. In Niswara it is stated that the concept map learning strategy can make it easier for students to learn independently and can relate one concept to another (Niswara, 2019). The implementation of the Project Based Learning (PBL) method is also accompanied by the use of concept maps. Concept maps are simple learning media and can represent all the concepts in the material. One of the purposes of concept maps is to train students to conclude concepts from the material being studied. A concept map is an image that describes the structure of the concept, namely the relationship between concepts from an image that states a meaningful relationship between the concepts of a subject matter that is connected by a conjunction. Therefore, concept maps will encourage students to connect concepts during learning, so that students will more 
easily understand the lesson. The application of concept maps can make learning more interactive and active and can make it easier for students to learn so that students will more easily understand the lesson(Abdulhak, 2012). In Abdulhak 's it is stated that the application of concept maps can make learning more interactive and active and can make it easier for students to learn so that students will more easily understand the lesson. In Mustafa's research (2013) it is stated that the application of concept maps can make learning more interactive and active and can make it easier for students to learn.

\section{Sevima Edlink App}

Submission of Project Based Learning (PBL) learning methods. What is delivered through the Sevima edlink application is an android-based application devoted to the world of education which aims to provide a learning space that bridges teachers and students in learning activities that can be done anytime and anywhere with more flexible study times. substantial, it should not be different from the real class. The lecturer plans to build a virtual class and use all the appropriate technology for the students of the course being taught. Lecturers should create an effective learning environment according to what has been previously planned.
The features in this application that facilitate interaction between lecturers and students are discussion forums, sharing features, class assignments, info, events and surveys. In addition, researchers take advantage of the private message feature in the application to connect personally with students with the aim of being a place for outpouring and providing student motivation related to activities lectures. Here's an initial look at Sevima Edlink:

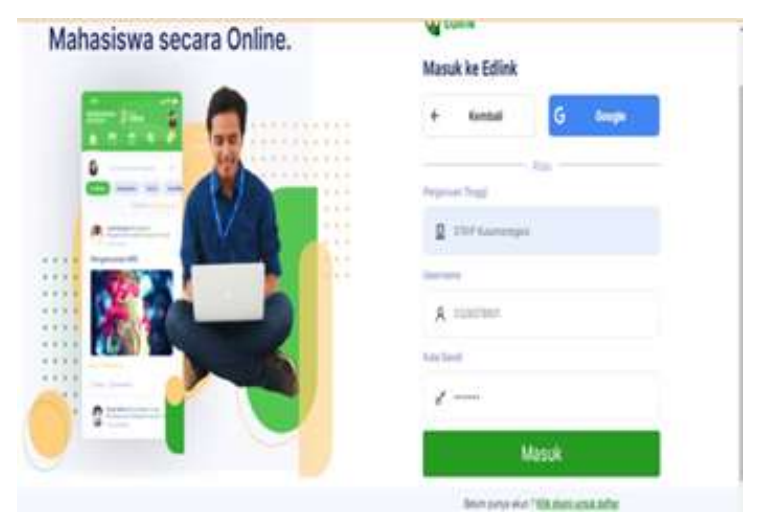

\section{METHOD}

This study used action research method, the role of the researcher is as an active actor, researching and directly involved in the entire teaching and learning process (research), starting from preobservation activities, planning, to the stage of reflection in each. In addition, researchers act as planners, implementers, processors, and data analyzers. Besides, this research is collaborative because it involves other parties, namely lecturers (collaborators). Referring to Kemmis, which was also stated by Mills and Madya, 
this action research procedure includes preobservation, followed by planning, action and observation, and reflection in the first cycle to the third cycle. The data collected is in the form of qualitative and quantitative through several data sources, namely lecturers, students, tests, and documents. Data collection and analysis is based on four key parameters, namely primary data, instruments, actors of analysis, and data analysis. To find out the improvement of students' English academic essay writing skills, quantitative data was collected.

In this study, qualitative data in the form of processes and information about the use of Project based Learning (PBL) learning methods through the Sevima Edlink application were collected from student assignments and researchers' observations on reflection activities carried out by students after the activity. This research will follow action research procedures which are research cycles including: (1) pre-observation, (2) planning, (3) action implementation, (4) observation, and (5) reflection. Research data consists of qualitative data and quantitative data. The qualitative data of this research is in the form of events and information about English academic writing skills before and after the implementation of learning using the Project based Learning (PBL) learning method through the Sevima Edlink application.

In this study, the data collection instruments used include: documents, and giving assignments/tests. Document review is carried out on the lesson plans that have been prepared; such as syllabus, learning outcomes, or personal notes, while the test is carried out to measure the level of success achieved by students before the implementation of the action and after the implementation of the action in learning. Initial tests are given to identify student deficiencies or weaknesses in academic writing and at the end of each cycle to determine the improvement in the quality of the results obtained by students. To avoid the subjectivity of the rater, this assessment is carried out by collaborators. The validation of this research instrument uses logical validation which consists of content and constructs validation and uses retest reliskill. Meanwhile, data validation was checked through triangulation. The main instrument in data collection is the researcher himself.

The data research was carried out referring t0 (Cresswell, 2008), namely the Experiencing Technique, through recording observations by researchers and collaborators during the implementation of actions for qualitative data and Examining Techniques, through examining the test 
results of students' English academic essay writing skills for quantitative data. The researcher also uses an inter-reiter agreement where the final result of the test assessment is the result of the two collaborators. Qualitative data analysis was carried out by researchers by referring to Miles and Huberman in Hopkins through an interactive model data analysis matrix consisting of the following steps. Data reduction which includes the process of selecting, concentrating, paying attention, simplifying, and transforming the raw data that appears in the field notes. Presentation of data (data display), presenting data into information that allows researchers to carry out the next stage. Conclusion drawing/verification, namely the researcher verifying the data based on the data that has been presented (Hopkins, 2002). The analysis of quantitative data by comparing the percentage of students' English academic essay writing skill test results at the beginning of the test, the post-test at the end of the first cycle with the post-test results at the end of the second cycle.

\section{DISCUSSION}

\section{Student Initial Skills}

Based on the initial abilities collected at the pre-observation stage, it is known that the problem faced by the 6th semester students of the STKIP
Kusumanegara English Education Study Program is the low skill of writing English academic essays due to the low attitude and interest in learning academic writing skills. Therefore, the solution found by the researcher was to try out the Project based Learning (PBL) learning method through the Sevima Edlink application. At the second meeting. The results of the initial skills test for writing student academic essays can be seen in the graph and description below:

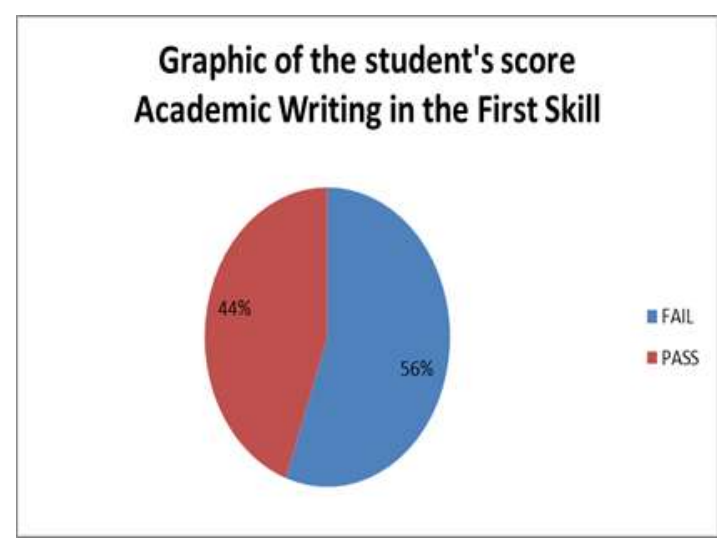

Figure 1. Students' Grade Chart in First Skill

Based on the graph above, it can be described that in the initial test of academic essay writing skills only $44 \%$ of 15 students were able to achieve a minimum score of 75. This shows that it is very necessary to improve students' academic writing skills. Of the four academic essay writing assessments (Task response, Coherence and Cohesion, Lexical Resource, Grammatical Range and Accuracy), the most prominent assessment criterion is task response. So it 
can be concluded that the results of the initial skills test for writing academic essays for students of the STKIP Kusumanegara English Education Study Program are still far from what the researchers expected.

Formulation of Action Plan and Observations

In accordance with the action research procedures, action plans and observations are formulated by determining the focus of observations and actions, action procedures, schedules, implementation scenarios, data collection tools and techniques. Based on the results of initial observations, the researchers developed an action plan as follows:

\section{First Cycle}

The purpose of this research is to improve students' English academic essay writing skills. As for the aspects that will be improved are task response, coherence and cohesion, lexical resource, grammatical range and accuracy, then the plan of action taken is as follows:

1. Researchers and collaborators develop learning scenarios

2. Students are given a brief explanation about writing academic essays using the Project based learning (PBL) learning method through the Sevima edlink Teknik application which will be assessed.
3. Students, researchers and collaborators discuss the concepts and steps that must be taken in learning to write academic essays using the Project based learning (PBL) learning method through the Sevima edlink technique application step by step.

The following is a graph of the results of the post-test of academic essay writing skills in Cycle I

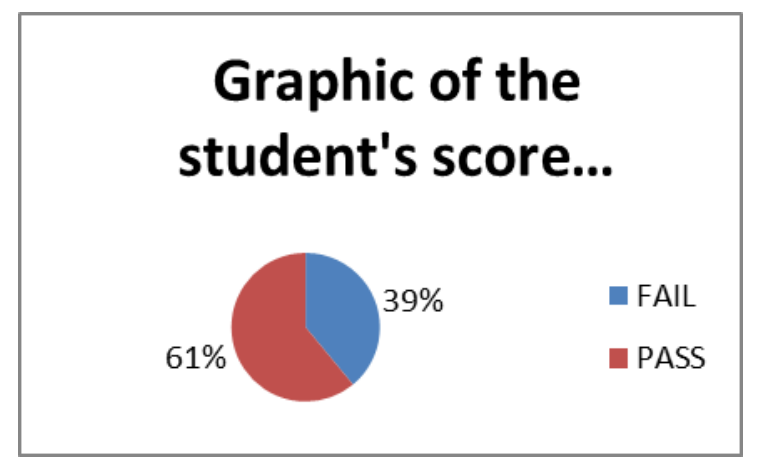

Figure 2 Students' Grade Chart in Cycle I

All participants' scores increased from the initial skills test to the fourth cycle I test for academic essay writing assessments, only coherence and cohesion did not decrease.

Based on the results of the observation of the implementation of the action, the results of the academic essay writing skills test were found that:

1. The first stage in the cycle was addressed by the participants with rigidity. At the beginning of this learning process, students felt stiff because they listened to the spoken 
discourse first and then wrote the key words from the text that was heard.

2. The second stage is filled with questions about how to write text keywords and reconstruct the text.

3. Participants reconstruct the text more easily because they have written the keywords they have listened to.

4. Participants did not look bored with teaching activities because the Project based learning (PBL) learning method through the Sevima Edlink application made it easier for students to practice academic writing.

5. The achievement of the student's skill target can be seen from the increase in the presentation of the initial writing skills test and the test in cycle one after being given treatment using the Project based learning (PBL) learning method through the Sevima Edlink application from $44 \%$ to $61 \%$.

\section{Second Cycle}

Based on the results of the reflection in Cycle I, a class action plan for Cycle II was drawn up. The implementation of the actions in cycle II is a continuation of cycle I. Learning in cycle I has not yet reached the set indicators. Thus it is necessary to continue in the next cycle. Learning in cycle II, each meeting lasts 100 minutes and is carried out in the lecture room. The results of the reflection in Cycle I were declared to have not been successful, and the success of this action was more due to the existence of learning methods that might have just been applied in learning to write. In the discussion between the researcher and the collaborator, the researcher conveyed the advantages and disadvantages during the learning process. Taking into account the various weaknesses that are still being carried out, the researchers and collaborators discuss the following matters:

1. The quality of learning to write academic essays with the dictogloss teaching technique needs to be improved. Continuing the Cycle I action by using the Project based learning (PBL) learning method through the Sevima Edlink application, the discourse of the dictated text may be even more real so it is more interesting to write.

2. Explaining to students to focus more on listening to recorded text discourse so that writing keywords is easier.

3. Improve students' academic essay writing skills by paying attention to the essay writing process starting 
from the introduction, body and conclusion.

The following is a graph of the results of the post-test of academic essay writing skills in Cycle II

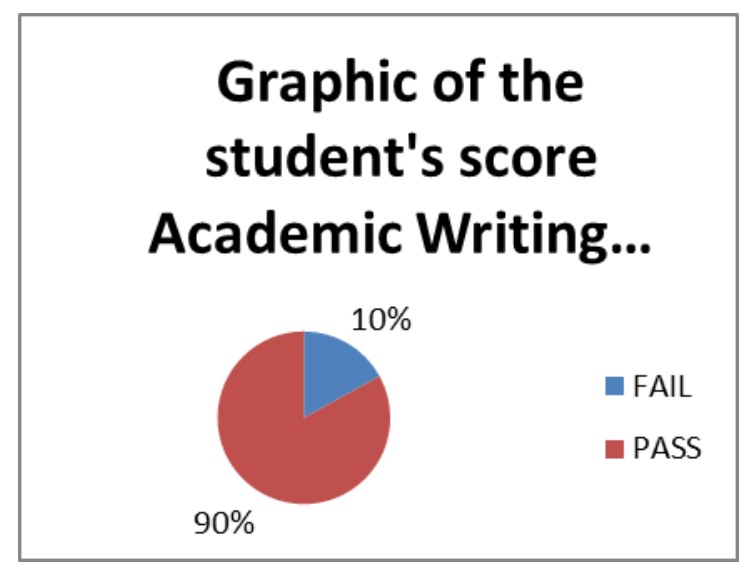

Figure 3 Students' Grade Chart in Cycle II

Based on the first and second cycles, it can be said that there is an increase in student academic writing skills using the Project based learning (PBL) learning method through the Sevima Edlink application. This can be seen from the percentage between cycle 1 and cycle 2 from $61 \%$ to $90 \%$. Based on the stage of implementing the actions and observations in cycle II, the results of the reflection are stated as follows:

1. Questions about vocabulary and grammar as part of how to construct words or sentences received a lot of attention from the participants.

2. Although the time required is longer, it is easier for participants to understand how to write academic essays using the Project based learning (PBL) learning method through the Sevima Edlink application.

3. Participants more easily understand how the structure of writing academic essays starts from task response, coherence and cohesion, lexical resources, to grammatical range and accuracy. There was a significant increase in academic essay writing skills where in Cycle I as many as $61 \%$ of students. In Cycle II. f. $90 \%$ of the total 15 participants.

The conclusion from the implementation of the second cycle of action is based on the reflection stage which shows that the indicators of research success have been achieved, namely $90 \%$ of participants can meet the target of $80 \%$. Although there are a few problems that arise such as the lack of vocabulary, grammar so that the reconstruction stage is a bit overwhelmed. Likewise with his enthusiasm for learning and boredom because he often writes essays. Based on the results of the reflection above. It was concluded that the research had fulfilled all the indicators of research success. Therefore, the research does not need to continue to the next cycle. 
Academic essay writing skills are conceptually understood as a way of using language to communicate through productive cognitive mechanisms in the form of writing that has good and correct aspects, including task response, coherence and cohesion, lexical resources, and grammatical range and accuracy. Most students complain about being confused about writing thesis, assignments given by lecturers, papers, and answering essays during exams. On the other hand, academic writing skills in English are indeed a target skill that must be improved because it makes it easier for students in the last semester to write a thesis. Academic essay writing skills are also very useful for continuing studies at a higher level. In cycle I, participants with rigidity.

At the beginning of this learning process, students felt stiff because they listened to the spoken discourse first and then wrote the key words from the text that was heard. The second stage was filled with questions about how to write text keywords and reconstruct the text.

In cycle II, participants awkwardness was still visible even though it was a little. In the course of this cycle a lot is discussed about sentence construction. Participants are familiar with the structure of writing academic essays (paragraphs). They are able to reconstruct the text more easily, although there are still some mistakes in word choice, grammar and so on. The test results of academic essay writing skills in cycle II have increased. Although these results only meet the minimum indicators set, but this is a major progress for the participants and the researcher's success in applying a technique that has never been applied before. The following graph shows the increase in the score of English academic essay writing skills starting from the initial test, post-test cycle I to cycle II.

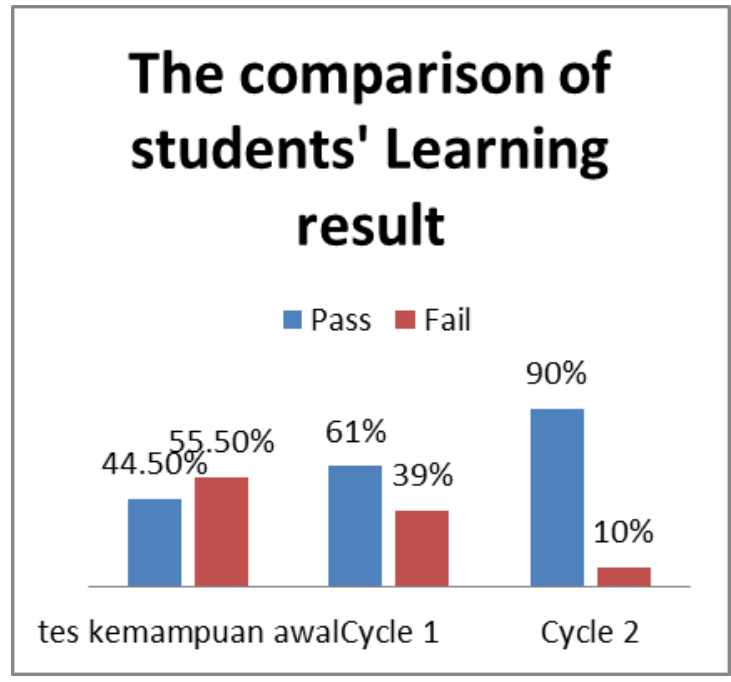

\section{CONCLUSION}

The conclusions that can be drawn in this action research are as follows: 1). The implementation of learning English academic essay writing skills for students of the STKIP Kusumanegara English Education Study Program went well and smoothly, namely by applying the Project based learning (PBL) as a learning method. 
through the Sevima Edlink application in the learning. Initially, they experienced stiffness and difficulty so that they did not run optimally because both collaborators and students were not familiar with and inexperienced with this technique. But after 18 participants. In the first cycle the increase only reached $44 \%$ of 18 students, while the second cycle increased by $90 \%$ of 18 students. In the view of the researcher, the fulfillment of all indicators of research success is a success in the application of the dictogloss teaching technique which was applied for the first time in the class running 4 times in the first cycle ending and entering the second cycle, learning using dictogloss teaching techniques can run smoothly. The actions taken in the Project based learning (PBL) learning method through the Sevima Edlink application in each round were carried out by students with enthusiasm and full of motivation. Likewise, the results of the reconstruction at each meeting experienced a drastic increase in accordance with the assessment aspects of task response, cohesion and coherence lexical resources, grammatical range and accuracy 2). The results of students' academic writing skills can be improved through the Project based learning (PBL) learning method through the Sevima Edlink application. This is indicated by the number of students who experienced a drastic increase in essay writing skills from cycle I to cycle II. There is a significant increase in academic essay writing skills where in the post-test Cycle I with a percentage of $61 \%$ and $90 \%$ in the post-test Cycle II.

\section{REFERENCES}

Abdulhak, I. 2012. (2012). Penerapan ICT dalam Pembelajaran di Madrasah", dalam Bahan Ajar Pelatihan Peningkatan Kompetensi Pembelajaran Berbasis ICT Bagi Guru Madrasah Se-Indonesia. Yayasan Idea Cendekia.

Cresswell, W. J. (2008). Educational Research: Planning, Conducting, and Evaluating Quantitative and Qualitative Research. Cambridge University Press.

Hopkins, D. (2002). A Teacher's Guide to Classroom Research. Open University Press.

Niswara. (2019). Pengaruh Model Project Based Learning Terhadap High Order Thinking Skill. Pengaruh Model Project Based Learning Terhadap High Order Thinking Skill. Mimbar PGSD UndekshaPGSD/Article/View/17493, 2(7), 85-90.

Thomas, J. W. (2000). A review of Research on PBL. Http://Www.Bobpearlman.Org/, 2. 